\title{
The Environmental Implications of Redistributive Land Reform
}

Malcolm M Combe*

Keywords: Land reform, environment, redistribution, community, localism, right to buy, Scotland

Ownership of land is important for a number of reasons. One reason is the agenda setting role the landowner has in terms of its use, which in turn has an impact on the environment. Environmental law plays a role in regulating the use of land, as do other devices such as planning law and private law controls including the law of nuisance, but absent such regulation the decisions of the owner are crucial. Land reform, by which it is meant the process that is geared towards the reallocation of property rights, either: changes who is invested with that crucial decision-making power; or influences the decision making of an existing owner, who might act in a way to negate any policy argument for reallocation of ownership. Both of these reactions can impact on the environment. How well are those impacts understood, and to what extent do they feature in the law-making process or the application of land reform measures? This paper will use the contemporary Scottish scene, particularly its two land reform statutes of 2003 and 2016, to scrutinise where the environment sits in the land reform debate there, which in turn will provide an opportunity to assess the environmental impact of specific land reform measures and where the environment has featured in a specific land reform process.

\section{INTRODUCTION}

In the 2011 edition of the Environmental Law Review, a Book Review began thus:

Environmental law is a fascinating subject. It is an area with which this reviewer would not claim any particular expertise, which is a strange claim to make at the outset of a review in an environmental law journal. ${ }^{1}$

Some five years hence, that same reviewer -the author of this article - retains a certain diffidence when venturing into the field of environmental law, but (as noted in that same review) that diffidence is dispelled when the more comfortable terrain of property law is encountered. It is that legal terrain which is the subject of this article, albeit with a decidedly environmental slant.

Another reason for my mitigated timidity during this further foray into the Environmental Law Review is that I was invited to participate in a lecture at the University of Edinburgh on the subject of environmental law. ${ }^{2}$ Whilst I might not have been a prime candidate for a traditional environmental theme, the cast narrowed somewhat when the organisers of the lecture targeted the topic of land reform in Scotland, albeit framed in a way that put the environmental implications of such reform to

\footnotetext{
* School of Law, University of Aberdeen. Thank you to the two anonymous referees who commented on this piece.

${ }^{1}$ M. M. Combe, 'Book Review Andy Wightman The Poor Had No Lawyers: Who Owns Scotland (and How They Got it)' Env L Rev 13 (2011) 242. Since that review, the book in question has been released in paperback and has now reached its third edition (Birlinn: Edinburgh, 2015).

${ }^{2}$ The $23^{\text {rd }}$ Brodies Environmental Law Lecture was delivered by the author, Dr. Jayne Glass (Centre for Mountain Studies, Perth College, University of the Highlands and Islands) and Dr. Calum MacLeod (School of GeoSciences at the University of Edinburgh). Details of this and other lectures are available at http://www.law.ed.ac.uk/other areas of interest/events/brodies lectures on environmental law.
} 
the fore. Perhaps it is a truism that the allocation of property rights in any legal system can have profound environmental implications - a point evidenced all too well by the acceptance of my earlier review of a text about who owns Scotland in the Environmental Law Review, and fortified by the lecture unashamedly linking land reform and the environment - but it remains a topic worthy of scrutiny. Important questions remain, including whether and how the truism can be tested, and exactly where the environmental variable sits in any land reform equation.

That recent lecture and the contemporary Scottish land question provide the spark for this paper, which will explain the background position then analyse how the environment features in the Scottish scene; a scene which has notably combined the environment and land reform in one Scottish Ministerial role. ${ }^{3}$ The analysis will differentiate reform measures that affect all landowners and those that seek to facilitate a change of owner, normally to a new owner that is somehow deemed more worthy than the current owner. It is that policy oriented reallocation of property that is the focus of this paper, particularly as found in the Land Reform (Scotland) Act 2003 ("the 2003 Act"), the Community Empowerment (Scotland) Act 2015 ("the 2015 Act") and the Land Reform (Scotland) Act 2016 ("the 2016 Act"). After considering various policy justifications for why a priority over an existing landowner might be offered, the paper will specifically consider whether those justifications make sense in terms of environmental law, before suggesting some lessons that could be learnt, whether for Scotland or for further afield.

\section{WHAT SORT OF LAND REFORM?}

Land reform is a huge topic. ${ }^{4}$ Any essay on the subject needs to be carefully demarcated. The first task is to explain exactly what is meant by land (law) reform, ${ }^{5}$ which for present purposes can be taken to mean state intervention in the regulation of immoveable property. ${ }^{6}$ Perhaps the more important issue for present purposes is what type of land reform is at issue: just as there are lots of ways to parcel up land, there are lots of ways to parcel up land reform.

One broad distinction, which divides into two categories, is between law reform that is meant as natural evolution as opposed to law reform that represents a definite policy shift. The former would be geared towards simplifying or somehow modernising land law, perhaps eliminating anomalies or esoteric points of current regulation. ${ }^{7}$ The latter makes a distinct change in the law, normally giving

\footnotetext{
${ }^{3}$ Aileen McLeod MSP was appointed the Scottish Minister for Environment, Climate Change and Land Reform on 21 November 2014.

${ }^{4}$ Consider the recent South African monograph J. M. Pienaar, Land Reform (Juta: Cape Town, 2014).

${ }^{5}$ The 'law' is normally dropped, but the triplet 'land law reform' is arguably more accurate, as the words 'land reform' could be used in a context that implies improvement of the land itself.

${ }^{6}$ As with many legal systems, the question of what is moveable property or immoveable (also known as heritable) property in Scots law can be tricky (in terms of whether something forms part of land after being attached to it). No analysis of that will be made here. Tangentially, in Scots law the accepted spelling is 'moveable' rather than 'movable'.

${ }^{7}$ In one analysis, Howell breaks legislative land reform into four subcategories: legislation that codifies existing law; legislation that corrects an acknowledged difficulty with the law; legislation which simplifies the law; and legislation to make a direct change in the law (J. Howell, 'The Dangers of Reform' in P. Jackson and D. C. Wilde (eds), The Reform of Property Law (Dartmouth: Ashgate Publishing, 1997) 54 at 59-60). Another treatment by Steven divides the reasons for reform into five categories, again classifying the political dimension separately. A. J. M. Steven, 'Scottish Land Law in a State of Reform' 2002 Journal of Business Law 177 at 178-179. This is
} 
expression to the government's political program in the process. It is the latter policy oriented land reform that is being looked at in this essay.

Another broad but binary distinction is between measures that affect all landowners as against measures that seek to directly change the landowner. For the former, blanket measures would include the Natura 2000 regime for habitats and birds, ${ }^{8}$ SSSIs,,${ }^{9}$ fiscal reform, and Part 1 of the 2003 Act. The last example is conveniently branded as a land reform measure, and the statute in question actually provides a handy comparative microcosm. This is because Part 1 of the 2003 Act affects all landowners and, as shall be seen below, Parts 2 and 3 are (to varying degrees) geared towards changing the landowner. Part 1 itself introduced statutory rights of public access over Scottish land, airspace and inland waters, in a similar but slightly more liberal way to the English and Welsh Countryside and Rights of Way Act 2000 and Marine and Coastal Access Act 2009.. ${ }^{10}$

Whilst such measures have a blanket effect, it would be simplistic to think that they do not affect different landowners in different ways: ${ }^{11}$ adapting Orwell, some owners are more equal than others. To develop one example, the rights of access introduced by the 2003 Act affect the great outdoors as a whole, subject to certain recognised exceptions normally linked to the characteristics of land. Although these do apply irrespective of who owns the land, litigation seems to establish that one of these recognised exceptions - which makes provision for a private garden area around a residence applies in such a way as to mean bigger (and more expensive) houses can enjoy bigger gardens. ${ }^{12}$ Flipping the perspective around, a measure that capped landownership to a certain amount would force large landowners to reorganise their affairs, but any need to reorganise would bypass smallholders. ${ }^{13}$ Turning to taxation, this too might begin from a position of uniform effect, but it is

discussed in M. M. Combe, 'Parts 2 and 3 of the Land Reform (Scotland) Act 2003: A Definitive Answer to the Scottish Land Question?' 2006 Juridical Review 195 at 195-196.

${ }^{8}$ That is to say, the Birds Directive (Directive 2009/147/EC of the European Parliament and of the Council of 30 November 2009 on the conservation of wild birds) and the Habitats Directive (Council Directive 92/43/EEC of 21 May 1992 on the conservation of natural habitats and of wild fauna and flora).

${ }^{9}$ Sites of Special Scientific Interest, as regulated by the Nature Conservation (Scotland) Act 2004.

${ }^{10}$ See further R. R. M. Paisley, Access Rights and Rights of Way (2006) (The Scottish Rights of Way and Access Society (Scotways): Edinburgh, 2006). The most detailed treatment, including a comparison with the English position, is provided by J. A. Lovett, 'Progressive property in action: the Land Reform (Scotland) Act 2003' (2011) 89 Nebraska Law Review 739. See also M. M. Combe, 'Get off that Land: Non-Owner Regulation of Access to Land' 2014 Juridical Review 287.

${ }^{11}$ It would also be simplistic to think that nature conservation laws that have a blanket effect will always have predictable effects for the environment: as noted by Trouwborst, 'the effect of the law on conservations conflicts is not straightforward': A. Trouwborst, 'Law and Conservation Conflicts' in S. M. Redpath, R. J. Gutiérrez, K. A. Wood and J. C. Young (eds), Conflicts in Conservation: Navigating Towards Solutions (Cambridge University Press: Cambridge, 2015) 108 at 112. Such matters are beyond the scope of this paper. 12 Gloag v Perth and Kinross Council 2007 SCLR 530, discussed in M. M. Combe, 'No place like home: access rights over "gardens"' (2008) 12 Edinburgh Law Review 463. The test that has contributed to different treatment for land around different sized homes has been termed the 'property specific objective test': Lovett, above n. 10 at 791-808.

${ }^{13}$ Such measures are recognised internationally: see the Voluntary Guidelines on Responsible Governance of Tenure of the Food and Agriculture Organization of the United Nations (Rome, 2012), where it is noted (at 15.2 ) that 'States may consider land ceilings as a policy option in the context of implementing redistributive reforms.' There is no upper limit to ownership of land in Scotland, but a cap on ownership was raised as a possibility in the recent Final Report of the Land Reform Review Group, The Land of Scotland and the Common Good (The Scottish Government: Edinburgh, 2014). At Part 6 (Land Ownership and Use), Section 24 (Pattern of 
clear that the introduction of a land value tax based on area of land owned or controlled by a taxpayer would particularly affect those with larger landholdings. The UK does not operate such a land value tax regime, but it does provide for taxation (or relief from taxation) for certain land uses. Targeted fiscal reform can make a current land use less profitable or an alternative land use more profitable, ${ }^{14}$ depending on the policy direction of the government of the day. (Such steps may indirectly trigger a voluntary transfer, albeit an encouraged voluntary transfer, in that the owner may decide the new regime is not one she wants to contend with, but even if that were to happen it would stem from a starting point of all owners being subject to the same regime.)

That is to be compared with reforms that seek to change the owner. Reallocation or control of property rights is a challenging area for many jurisdictions. Such reallocation or control is normally subject to international or constitutional oversight. For jurisdictions within the remit of the Council of Europe (like the UK), Article 1, Protocol 1 of the ECHR provides for the peaceful enjoyment of possessions, with disruption to that enjoyment only allowed in certain circumstances. ${ }^{15}$ Glossing over those rules for now, examples abound of situations where one owner has been preferred to another, from historic divisions of Scottish commonties ${ }^{16}$ to tenants being given a right of acquisition. ${ }^{17}$ Examples of such targeted reallocation reforms will be examined in more detail below.

The subject of this essay looks at the combination of the second strands of each of the broad categories offered above, namely the overt policy oriented reallocation land reforms. ${ }^{18}$ One thing that this essay will explicitly avoid critiquing is the not insignificant separate issue of what kind of priority non-owners should be given towards achieving that reallocation. Whilst that will not be

Rural Land Ownership), paragraph 25 of the Final Report, the Group raised the view 'that there is a scale at which the ownership of a large extent of Scotland's land by one private owner should be considered inappropriate, and contrary to the public interest.' No scale was actually proposed, that being left for the Scottish Government to take forward. In the event, the Scottish Government decided not to do so. This Group is explained further below and in M. M. Combe, 'Land Reform Revisited: The Land of Scotland and the Common Good' (2014) 18 Edinburgh Law Review 410.

${ }^{14}$ For example, consider the tax exemption that was introduced for certain rural sporting activities (primarily shooting) in the 1990s, which exemption is to be removed by Part 6 of the Land Reform (Scotland) Act 2016. Consider also the new Land and Buildings Transaction Tax surcharge for second homes. Scotland reformed its taxation of property transactions via the Land and Buildings Transaction Tax (Scotland) Act 2013. There is taxation of most land transactions in Scotland (operating in a similar way to Stamp Duty Land Tax in the rest of the UK), but there is no national system for taxation of land values. There is taxation at a local authority level linked to property valuation.

${ }^{15}$ See generally R. Reed and J. L. Murdoch, Human Rights Law in Scotland $3^{\text {rd }}$ edn [XXX $4^{\text {th }}$ edn due 14 July 2016] (Bloomsbury: London, 2011) chapter 8.

${ }^{16} \mathrm{~A}$ point touched on in my earlier book review, in the context of the gradual depopulation of the area immediately around Bennachie in Aberdeenshire: Combe, above $\mathrm{n} .1$ at 243.

${ }^{17}$ Such a policy being at issue in the important human rights case of James v UK (1986) 8 E.H.R.R. 123, where the reallocation reform in the Leasehold Reform Act 1967 was found not to breach the Article 1, Protocol 1 rights of the landowner.

${ }^{18}$ This is not meant as an exhaustive analysis of the way land reforms can be analysed. Another way to do so is to separate out what might be thought of as top-down 'state-led land reform' and less directive 'market-led land reform', as discussed in E. Lahiff, S. M. Borras Jr and C. Kay, 'Market-led agrarian reform: policies, performance and prospects' (2007) 28(8) Third World Quarterly 1417. Yet another alternative can be derived from Honoré, who considers a spectrum of transfer of ownership models by placing active systems at one end of a spectrum and conservative systems at the other, and accordingly land (or wider property) reform would be something that shifts where on that spectrum a system is positioned: A. M. Honoré, 'Ownership', in A. G. Guest, Oxford Essays in Jurisprudence (Oxford University Press: Oxford, 1961) 106 at 137. 
critiqued in detail, for completeness it is necessary to set out what those tools towards reform might be.

\section{What tools should be used?}

There are various reallocation models available, moving along a spectrum from:

- a right to bid, as can be found in Part 5 of the Localism Act 2011 in England and Wales;

- a right of pre-emption, as bestowed on communities by Part 2 of the 2003 Act and on tenants of agricultural holdings by Part 2 of the Agricultural (Holdings) Scotland Act 2003; or

- a right to force a sale, as has been enjoyed by certain tenants in social housing across the UK, certain esoteric Scots law tenants like the tenant-at-will or a crofter, ${ }^{19}$ and crofting communities in terms of Part 3 of the 2003 Act. Further strong rights of community acquisition have been introduced by the 2015 Act and Part 5 of the 2016 Act.

Not quite making it onto the spectrum at all would be a right for community engagement or a role for community planning (unless, of course, a lack of engagement in such process led to a potential reallocation of ownership), ${ }^{20}$ but those reform measures remain important as they can allow a community to take stock and work out what its priorities are. It might also be noted that the provisions of the Localism Act 2011 barely register on the spectrum, as they do not lock an owner into a process that leads to community acquisition like the Scottish community rights of acquisition do. Instead, the Localism Act 2011 only provides 'an additional layer of complexity in the disposal and re-purposing of "traditional" community hubs'. ${ }^{21}$

One potential reform that does not fit comfortably onto the spectrum is a situation where someone can force an auction of property, without necessarily participating in the resulting process. That reform would trigger a change rather than a substitution of ownership, albeit in the hope the new owner is somehow more benevolent towards the instigator of the change than the previous owner. ${ }^{22}$

Returning to the spectrum, these various tools might not actually lead to a transfer, especially in circumstances where a non-owner's powers lead to dialogue and in turn encourage a landowner to change her behaviour. If the land reform policy is more concerned about what use the land is put to

\footnotetext{
${ }^{19}$ For crofters, the scheme is found in the Crofters (Scotland) Act 1993, ss.12-19A, after initial introduction in 1976. For tenants-at-will, see the Land Registration (Scotland) Act 1979, s. 20.

${ }^{20}$ As can be found in Part 4 of the 2016 Act.

${ }^{21}$ Kevin Toogood, 'Assets of community value: a review of Part 5 Chapter 3 of the Localism Act 2011 ' 20144 Journal of Planning \& Environment Law 423 (providing 'pubs, small sub-post offices and community centres' as examples of such hubs). Toogood goes on to note that the Localism Act 2011 is limited in its effect by its terms, for two reasons. First, the moratorium (under s. 95) will only bite if the nomination by the community that land should be an asset of community value (under s. 89) is made before any agreement for sale or lease becomes binding. Second, 'the relatively short timescale within which a community body must give notification of its interest requires that body to be in a position to put together a bid within a commercially sensible timescale. Ultimately, the Act only gives that body the right to be considered as a bidder: there is no requirement to sell to it if its bid is not satisfactory.'

22 The Final Report of the Land Reform Review Group above n.13) discusses the possibility of a compulsory sale order, above n 13 at Part 5 (Land Development and Housing), Section 20 (Urban Renewal), paragraphs 21-32.
} 
rather than simply effecting a change in ownership, an end result that leaves the underlying ownership unaffected is not problematic. Further (and much like the situation with reforms that are blanket in nature detailed above), there may be situations where an encouraged but voluntary transfer takes place, operating outside any statutory scheme. That being said, the more fastidious landowners might, quite legitimately, expect the exact land reform mechanism to be followed. It is in such situations that the effectiveness of a land reform measure is truly tested.

\section{Who gets those tools, and why?}

Much more could be written on the topic of what tools should be available for people to instigate change, but the key points to consider for this essay are: who gets access to the tools; and why such people are given tools that allow them to usurp or unsettle a landowner. All of that depends on context. The geopolitics, history, legal system, prevailing market conditions and much more will all have a part to play in determining if and when it is appropriate for a state to interfere in its system of land regulation. A non-exhaustive list of why a priority might be given would include:

restitution;

food security;

resource governance (and in turn related factors like population retention or revitalisation);

enterprise and/or breaking anti-competitive practices;

social justice; or

better management of the environment.

All of these will now be viewed through a decidedly Scottish prism, but (subject to the very important caveat about context just mentioned) lessons and analogies can and will be drawn from elsewhere. The first such insight comes from South Africa, where Pienaar offers a number of goals for land reform, one of which is that land reform 'enhances the protection of the environment and promotes sustainability'. ${ }^{23}$ That specific environmental goal will be analysed in greater detail after alternative justifications are considered.

\section{Why reform Scotland's land?}

What is driving the demand for land reform? In some jurisdictions, there might be an argument for restitution, as per one aspect of South Africa's reform, ${ }^{24}$ seeking to right a historical wrong where

\footnotetext{
${ }^{23}$ To oversimplify Pienaar, above n. 4, she notes that the main (global) goal of land reform is to reduce poverty and gross inequality (at 23), before listing thesupplementary goals 'promoting output, efficiency and growth in the agricultural sector', environmental and sustainability concerns, and supporting stability 'in its broadest sense' (at 24). She then expands to note the alternative arguments that land reform can have a role in "increased crop production; improved nutrition for poor households; 'ladders out of poverty' and a basis for economic growth; reduced social unrest and instability; reduced urban migration; and better environmental stewardship" (at 26), drawing on the work of R. L. Prosterman and T. Hanstad, 'Land Reform in the 21st Century: New Challenges, New Responses' (2006) 4 Seattle Journal for Social Justice 763.

${ }^{24}$ D. L. Carey Miller with A. Pope, Land Tenure in South Africa (Kenwyn: Juta, 2000), particularly chapter 7; Pienaar, above n. 4 at 209 and chapter 9.
} 
the person or community that has been wronged is identifiable. ${ }^{25}$ Irrespective of stories of Highland - or indeed Lowland - clearance, ${ }^{26}$ contemporary Scottish land reform tends not to be viewed as restitutionary. There might be a historical undercurrent to aspects of the debate, and modern historians continue to analyse and explain what happened to rural Scotland in the aftermath of the ultimate Jacobite failure at Culloden Moor in 1746, with the dismantling of the clan system and associated rural depopulation that followed. ${ }^{27}$ Even with that backdrop, it seems highly unlikely that restitution by way of a claim of native title to land or related indigenous rights would ever be successful in a Scottish court, ${ }^{28}$ but history undoubtedly features in the surrounding narrative.

Neither is it about providing subsistence agriculture for those who are starving nor shelter for those who are destitute, although notions about food security, sanitation and housing have been creeping into the Scottish debate, as a positive rights-based driver for land reform. ${ }^{29}$ For completeness, it should be noted that the food security argument - like so many land reform arguments - can cut both ways, and indeed the potential unsettlement of food supply has been cited by some as an argument against reform. ${ }^{30}$ The rights-based argument can also be deployed in favour of the landowner, who has a human right to peaceful enjoyment of her possessions except where that is disturbed in the public interest (non-arbitrarily and generally with compensation). ${ }^{31}$

\footnotetext{
${ }^{25}$ To take one recent example from Europe, Jews and the descendants of Jews that were subjected to forced sales in Nazi Germany can make a claim in relation to the relevant property, as demonstrated in D. Gold, Stolen Legacy: Nazi Theft and the Quest for Justice at Krausenstrasse 17/18, Berlin (Ankerwyck/American Bar Association: 2015) [and see http://www.theguardian.com/lifeandstyle/2015/aug/29/dina-gold-familyproperty-nazi-berlin-stolen-legacy-krausenstrasse].

${ }^{26}$ Many resources are available. In addition to Andy Wightman's already referenced polemic, a short selection includes J. Hunter, Last of the Free: A Millenial History of the Highlands and Islands of Scotland (Mainstream Publishing: Edinburgh, 1999), M. Fry, Wild Scots: Four Hundred Years of Highland History (John Murray Publishers: London, 2005) and (considering the Lowlands) T. M. Devine, 'Social Responses to Agrarian "Improvement": The Highland and Lowland Clearances in Scotland' in R. A. Houston and I. D. Whyte (eds) Scottish Society 1500-1800 (Cambridge University Press: Cambridge, 1989) 148. For one particular locality, the changing pattern at North and South Tolsta is detailed in Bill Lawson, Lewis: The East Coast, beginning with a "tack" (lease) being held by a tacksman of those holdings, with South Tolsta sublet to sixteen people. In 1829 the tacksman lost the lease, leading the land to go straight to the "crofters", then in 1851 clearance was mooted, and then in 1852 North Tolsta was cleared. (Birlinn: Edinburgh, 2011) 10-13

27 J. Hunter, Set Adrift Upon the World: The Sutherland Clearances (Birlinn: Edinburgh, 2015).

${ }^{28}$ Combe, above n. 7 at 201-202.

${ }^{29}$ To the extent that s. 98 of the 2003 Act has been amended (by the 2015 Act) to make explicit reference to the International Covenant on Economic, Social and Cultural Rights, which in turn raises the issues of food, sanitation and housing.

${ }^{30}$ The Telegraph, 'SNP land reforms "forget about food production"' 19 May 2015, available at http://www.telegraph.co.uk/news/politics/SNP/11614062/SNP-land-reforms-forget-about-foodproduction.html

${ }^{31}$ Two cases provide useful examples of what is and is not acceptable in human rights terms and (in turn) the devolution settlement established by the Scotland Act 1998. What is not acceptable is made clear in a series of cases about the Agricultural Holdings (Scotland) Act 2003 and the arbitrary imposition of a heavily regulated agricultural tenancy on a landlord without compensation, culminating in the UK Supreme Court case of Salvesen v Riddell [2013] UKSC 22. The various steps of that saga are analysed in M. M. Combe, 'Human rights, limited competence and limited partnerships: Salvesen v Riddell', 2012 Scots Law Times 193, 'Peaceful enjoyment of farmland at the Supreme Court' 2013 Scots Law Times 201 and 'Remedial Measures in Agricultural Holdings' 2014 Scots Law Times 70. What is acceptable is a properly considered piece of legislation that provides for the reallocation of property rights within a statutory scheme that allows a landowner to make representations throughout: Pairc Crofters Limited and Pairc Renewables Limited v. The Scottish
} 
The arguments for land reform you tend to see in Scotland can be characterised as being about enterprise - or so the First Minister of the time of the 2003 Act, Jack McConnell might have phrased it - when he explicitly noted the 2003 Act 'is not about righting wrongs inflicted centuries ago. Nor is it about hills or heather. It is about enabling people in today's rural communities to be ambitious and to take responsibility for improving their own lives. ${ }^{32}$

The pattern of landownership in Scotland has led some people to draw analogies with competition law in the EU, in that large entities are broken up if they use that dominance to abuse the market in which they operate. ${ }^{33}$ To make a proper analysis of whether that analogy holds for Scotland's land can be difficult or laborious, owing to the occasionally patchy information about who owns what available at present. (That patchiness is twofold, sometimes relating to a lack of clear data available on public registers for land, ${ }^{34}$ or perhaps where there is a lack of clarity about who controls the landholding entity that is registered as owner, ${ }^{35}$ but steps are being taken in relation to both those aspects.) Wightman's empirical analysis ${ }^{36}$ contributed to a paper submitted to the Scottish Affairs Committee, which suggests a figure in the region of 432 landowners own $50 \%$ of the privately owned

Ministers [2012] CSIH 96. That saga is analysed in M. M. Combe, 'Ruaig an Fhèidh' (2011) 56(5) Journal of the Law Society of Scotland 54 and 'Ruaig an Fhèidh: 3' (2013) 58(2) Journal of the Law Society of Scotland 31. 32 The Telegraph, 'Right-to-buy land reform may be extended to 500,000 more people' 20 August 2003 http://www.telegraph.co.uk/news/uknews/1439317/Right-to-buy-land-reform-may-be-extended-to-500000more-people.html. (That statement also serves as a prime example of a rejection of the restitution line of land reform in Scotland.)

${ }^{33}$ Such as Hunter, who sought to make 'a business friendly case...that the few privileged holders are crippling the market': J. Hunter, 'Review: Who Owns Britain' (2004) 46 (Winter) Scottish Affairs 52 at 53. There are hints at a critical view of monopolies in the Final Report of the Land Reform Review Group, where it is noted that present voluntary good land management practices 'should not disguise the fact that they do so at their own discretion and that the present arrangements provide limited sanctions against those who do not. This situation arises because of the degree of 'monopoly' control large land owners effectively have over land and other community interests, in ways that can determine the future of whole localities: above n. 13 at Part 6 (Land Ownership and Use), Section 24 (Pattern of Rural Land Ownership), paragraph 25.

${ }^{34}$ Scotland has operated a system of deeds registration for the transfer of land since the Registration Act 1617, before moving to a map-based system of registration of title that has been phased in since the Land Registration (Scotland) Act 1979. The transition has been slow, but is perhaps nearing resolution, with both the Scottish Government and Registers of Scotland committing to a rapid completion of the coverage of the Land Register to the whole of Scotland, in line with the recent Land Registration etc. (Scotland) Act 2012. See further: http://news.scotland.gov.uk/News/Target-set-to-register-all-of-Scotland-s-land-cc8.aspx.

35 In proceedings at the Rural Affairs, Climate Change and Environment Committee of the Scottish Parliament in the run-up to the 2016 Act, an estimate that some 750,000 acres of Scotland was owned via nontransparent entities was discussed and not doubted (Official Report of the Rural Affairs, Climate Change and Environment Committee, 7 September 2015 Report, Col 71 (Scottish Parliamentary Corporate Body: Edinburgh) at http://www.scottish.parliament.uk/parliamentarybusiness/report.aspx?r=10075\&mode=pdf. The figure appears in the magazine Private Eye Issue 1395 (26 June 2015). As for the implications of nontransparent ownership, George Monbiot provides one example of the "legal knots" occasioned by a structure involving companies based in Liechtenstein (although that situation was further complicated by the death of the Italian "landowner", who left no will): G. Monbiot, Feral, (Penguin: London, 2014) 99. The transparency point has also been made by Wightman, above $n$. 1 chapter 29 . These concerns have led to legislation aimed at improving access to information about who controls land, in Part 3 of the 2016 Act.

${ }^{36}$ Above n. 1. 
land in Scotland. ${ }^{37}$ That is a striking figure, and leads some to the observation that 'Scotland has the most concentrated pattern of private ownership in Europe, and possibly the world.' ${ }^{38}$

A related argument that flows from concentration of landownership is tied to ideas of social justice and fairness across society. That idea seems innately attractive to some political movements, especially when it is linked to notions about unearned wealth, but it should be stressed that not all landowners in Scotland fit the handy parody of landed gentry and some landowners will have invested in an asset which, at the time of investment, they were perfectly free to purchase and make plans for. Rendering property rights fickle or fragile can have an unsettling effect on the market. Another point about social justice and land reform is that land is but one part of the overall equitable mix of society and, as Merrill notes, any redistributive policies need to consider wealth as a whole rather than land alone. ${ }^{39}$ This a potentially huge topic and beyond the scope of this essay.

Another possibility is that reform is about the governance of land, which is particularly seen to be an issue when landowners are termed as 'absentee' (a point which can be compounded when a nonactive, non-resident owner is also non-transparent). To simplify, the argument would be that land is better governed when those who live or work on the land have a stake in its governance. This might bring related benefits in terms of population retention or revitalisation.

It is inherently tricky for a lawyer to make any authoritative statements about what form of governance is best for a resident community, but one notable example of community ownership in Scotland is the Stornoway Trust. This entity, established by the outgoing owner of the Isle of Lewis in 1924, owns some 69,000 acres in and around Stornoway. It is home to a large proportion of the Western Isles' population. ${ }^{40}$ More modern examples of community ownership include the islands of Eigg and Gigha, both of which have witnessed population increases since transfer to their respective community. ${ }^{41}$

37 J. Hunter, P. Peacock, A. Wightman and M. Foxley (with a foreword by lan Davidson MP), 432:50 - Towards a comprehensive land reform agenda for Scotland: A briefing paper for the House of Commons Scottish Affairs Committee, (2013) available at http://www.parliament.uk/business/committees/committees-a-z/commonsselect/scottish-affairs-committee/news/land-reform-inquiry/. By 'privately owned', state owned land is excluded, so the land owned by Forestry Commission Scotland (via the Scottish Ministers) does not feature in that analysis.

${ }^{38}$ A. McKee, C. Warren, J. Glass, and P. Wagstaff, 'The Scottish Private Estate' in J. Glass, M. F. Price, C. Warren and A. Scott, Lairds, Lands and Sustainability (EUP: Edinburgh, 2013) 62 at 65 . A similar statement is made by Monbiot about Britain as a whole (drawing on the work of Kevin Cahill) when he states that "we have one of the highest concentrations of landownership in the world", above n. 35 at 107: see further K Cahill, Who Owns Britain (Canongate: Edinburgh, 2002).

${ }^{39}$ T. W. Merrill, 'Property and the Right to Exclude' (1998) 77 Nebraska Law Review 730 at 754 . Whilst this may be true, compare the already highlighted observation of Pienaar that the main (global) goal of land reform is to reduce poverty and gross inequality, above n. 4 at 23. See also R. L. Prosterman, R. Mitchell and T. Hanstad (eds), One Billion Rising: Law, Land and the Alleviation of Global Poverty (Leiden University Press: Leiden, 2009).

${ }^{40}$ The high population of Stornoway is also linked to the natural harbour at Stornoway, amongst many other things, so it would be artificial to attribute every Stornowegian success to community ownership. See generally R. Hutchinson, The Soap Man: Lewis, Harris and Lord Leverhulme (Birlinn: Edinburgh, 2003).

${ }^{41} \mathrm{~J}$. Hunter, From the Low Tide of the Sea to the Highest Mountain Tops: Community Ownership in the Highlands and Islands of Scotland (The Islands Books Trust: Kershader, 2012). As regards the community acquisitions that have taken place under the 2003 Act, see C. Mulholland, G. McAteer, C Martin, L Murray, R 
Of course, communities are not insulated from all challenges of land management. The Isle of Gigha has faced some documented issues, particularly in relation to the debt owed by the community (and secured on its land) post acquisition. ${ }^{42}$ There are also some who point out communities, or indeed any incoming owner, are not necessarily skilled when it comes to land management, ${ }^{43}$ whilst others caution against models of community ownership that trap communities into their own circumstances. ${ }^{44}$ As with ideas of social justice, the best governance of land for a healthy community - whatever a healthy community actually is - is another issue that is potentially huge and will not be explored in further detail here. What will now be explored is the central theme of this essay, namely the environment.

\section{IS THE ENVIRONMENT A DRIVER FOR REALLOCATION OF PROPERTY RIGHTS?}

In the introduction to this essay, the truism that property rights can have environmental implications was raised. This is true now and it has been true for a very long time, as demonstrated by an historical example taken from a book of quirky Scottish facts about Scotland's Moray coast, relating to what is now a Site of Special Scientific Interest:

Culbin Forest, which stretches between Nairn and Findhorn... was once an area of sand dunes known as 'the Scottish Sahara'. The removal of grasses for thatch [emphasis added] had denuded the existing dunes which, in 1694, were swept up by a westerly gale, engulfing the whole community of Culbin, dwellings, a church, the great house of Kinnaird and a mass of livestock. Today the land has been stabilised by the planting of trees and hardy grasses, but occasionally the sands shift to reveal bits of the lost buildings underneath. ${ }^{45}$

That removal of grasses, whether by a proprietor directly or by a person entitled via a servitude (easement) right, caused a profound change to the environment in this instance. ${ }^{46}$ Farming practices

Mc Morran, E Brodie, S Skerratt and A Moxey, "Impact Evaluation of the Community Right to Buy" (Scottish Government Social Research: Edinburgh, 2015 at http://www.gov.scot/Publications/2015/10/8581.

42 The Sunday Herald, 'A tale of two islands as Gigha dream turns sour' 23 November 2014, at http://www.heraldscotland.com/news/13190772.A tale of two islands as Gigha dream turns sour/. I wrote a somewhat personal blog post about this situation: 'Gigha dream turns sour? Community ownership in Scotland' 23 November 2014 at https://basedrones.wordpress.com/2014/11/23/gigha-dream-turns-sourcommunity-ownership-in-scotland/.

${ }^{43}$ Education is clearly important and kicking out experienced land managers can have a big impact, as evidenced most clearly by Zimbabwe: see BBC News, 'Robert Mugabe admits Zimbabwe's land reform flaws' 27 February 2015 at http://www.bbc.co.uk/news/world-africa-31663267. There is separate question of how or where current owners might have acquired skills from, and whether the opportunities they have had have been the result of a system that unduly benefits some sections of a society but (as noted above) land is but one part of the equitable mix in any society and is difficult to consider in isolation.

${ }^{44}$ Consider Antinori, who notes that 'devolving responsibility may "enslave" local indigenous groups to the natural environment.' C. Antinori, 'Governance and Resource Management in Mexico's Community Forestry Sector' in J. Holder and C. Harrison, Law and Geography (Oxford University Press: Oxford, 2002) 307 at 310. ${ }^{45}$ C. Winn, I Never Knew That About Scotland (Ebury Press, 2007) 173.

${ }^{46}$ The land is now managed by Forestry Commission Scotland which, on its website, notes that in 1695 the old Scottish Parliament passed legislation specifically (but belatedly) to regulate the practice of removing thatch: http://scotland.forestry.gov.uk/activities/heritage/world-war-two/world-war-two-sites/culbin-ww2defences/history-of-culbin-sands. For a more modern analysis of what states should do to protect their ecosystems, consider O Woolley, Ecological Governance (Cambridge University Press: Cambridge, 2014). 
have caused environmental impact since before Robert Burns disturbed a mouse with his plough, ${ }^{47}$ and continue to do, with one example being the modern practices that have deprived corncrakes of their former British habitats in virtually all but the Hebrides of Scotland. ${ }^{48}$ Mankind has actively changed landscapes the world over. Land has been reclaimed, in Norfolk and the Netherlands. Land has been sculpted, creating terraces for wine in France and for agriculture in the Andes. There is even evidence that humans, rather audaciously, established terraces in that most remote of places in the British Isles, St Kilda. ${ }^{49}$ Farming on the tiny island of Boreray would have been a hard Atlantic existence, and the St Kildan way of life eventually came to an end in 1930 when the remaining human population was evacuated. That evacuation leads to another example of the environmental impact of the absence of humans: when the community there disappeared, a species of mouse that relied on the human population promptly became extinct.

What does this tell us about the allocation of land rights, and particularly ownership? Many of these examples are just as much about the environmental impact certain use (or non-use) of land has, as opposed to the impact of ownership per se. In fact, a recurring counter-argument to land reform is that use, not ownership, is what matters. ${ }^{50}$ That may be true, but what is undeniably true is that legal systems that recognise private property place the right to use as a crucial entitlement of the owner. In Scotland, building on Roman law notions of dominium, an owner generally has the right to use, enjoy, consume and dispose of a resource (subject to law or paction). ${ }^{51}$ This has an impact on the ground, as illustrated by a recent text on upland management which noted that property rights are:

'of fundamental importance as they have an impact on the status of the 'ultimate resource' from which all prospects for development, production and conservation in uplands are derived. $^{52}$

A more historic example also shows the profound impact an owner might have or, as in this case, the impact new sheep farming tenants might have. Sutherland is infamous for being an area of human clearance in the $19^{\text {th }}$ century, but the preference for sheep over men also led to the control of what was considered to be vermin: a point made by Hunter when he highlighted the deaths of 130 eagles, 317 'wildcats, [pine] martens and polecats', 516 ravens and 281 'hawks' between 1819 and $1821 .{ }^{53}$ Species protection rules might prevent such excesses of land management now, ${ }^{54}$ but that extreme example demonstrates the environmental impact an owner's choices can have. Imagining other

\footnotetext{
${ }^{47}$ Immortalised in his poem, To a Mouse: Poems Chiefly in the Scottish Dialect (The Kilmarnock Edition) (1786).

${ }^{48}$ See K. Jamie, Findings (Sort of Books: London, 2005) 92 and Monbiot, above n.35 at 263. Surprisingly, Monbiot narrates that he chanced on his corncrake on the Welsh coast.

${ }^{49}$ BBC News, 'Prehistoric finds on remote St Kilda's Boreray isle' 17 June 2011 http://www.bbc.co.uk/news/ukscotland-highlands-islands-13753643.

${ }^{50} \mathrm{See}$ http://www.scottishlandandestates.co.uk/blog/challenge-facing-agriculture-is-to-do-with-land-use-notwho-owns-it/.

${ }^{51}$ This formulation being taken from the Scottish institutional writer, Erskine, Il.1.1. See also K G C Reid, The Law of Property in Scotland (Butterworths/Law Society of Scotland: Edinburgh, 1996) paragraph 5.

${ }^{52} \mathrm{~J}$. Glass, A. Scott, M.F. Price and C. Warren, 'Sustainability in the uplands: introducing key concepts' in Chapter 1 of Glass, Price, Warren and Scott (eds), above n. 38 at 4.

${ }^{53}$ Hunter, above n. 27 at 259.

${ }^{54}$ As analysed in C. Reid, Nature Conservation Law, $3^{\text {rd }}$ edn (W. Green: Edinburgh, 2009). See also Woolley, above n. 46.
} 
possibilities for Sutherland or similar locations can very quickly take you into the realms of the counter-factual, but it does seem eminently possible that a resident community would not have taken the same approach to ecosystem management. ${ }^{55}$

The point about species protection rules links back to a wider point about land reform that has already been aired in the context of the importance of use rather than ownership: if proprietors are regulated properly in terms of what they can do for the environment, where ownership rests is irrelevant. So why reform for environmental purposes? Are resident communities, or perhaps even newly settled smallholders, ${ }^{56}$ inherently better for the environment than large estates? Although that is not the kind of question that might find a definitive answer in a legal journal, it is legitimate to raise the question in the hope commentators and indeed legislators will engage with it in future. It is also appropriate to raise a word of caution about land reform and the environment: the most highprofile conservation story of 2015 has been cast as a land reform story, in terms of the mismanagement of land by new Zimbabwean owners contributing to the death of Cecil the lion. ${ }^{57}$ Land reforms are normally passed in the hope of making things better, but care has to be taken to ensure the upheaval does not actually make things worse.

Another important yet obvious point is that not all land is the same. ${ }^{58} \mathrm{~A}$ change of ownership might not have a marked effect on what land of a certain character will be used for, and in turn the environmental impact of an ownership change would not be pronounced. Sticking with Scotland as an example, its landscape has been split into three land zones which can be simplified as high quality farmland, high (altitude) mountains, and a 'squeezed middle' in between. Scotland has a low proportion of better quality arable farmland, meaning that agriculture has a strong claim to be the key public interest land use in such areas. At the other end of the spectrum, there is a relatively limited range of land use options in the land classes of the higher and more exposed moorlands, hills and mountains. That leaves the squeezed middle, where there is a tricky balancing act to 'plan the

\footnotetext{
${ }^{55}$ In fact, the 2008 Report of the Committee of Inquiry into Crofting, normally referred to as the Shucksmith Report, noted the positive impact crofters had on (amongst other things) the environment, a view which was endorsed by the Land Reform Review Group: above n. 13 at Part 7 (Agricultural Land Holdings), Section 26 (Crofts), paragraph 12. Those crofters are only there because of legislation that restricts the otherwise wide autonomy of landowners. Useful as this crofting example might be, a technical clarification is necessary, as the crofting law structure is based on a model of leasing that is akin to absolute security of tenure that leaves underlying ownership of the land untouched, rather than redistribution of land itself. That said, crofts are clustered into townships with associated common grazings for use by members of a community of tenants, so there is something of a tenant cooperative in operation.

${ }^{56}$ Such settlement happened in the aftermath of World War I, by means of the Land Settlement (Scotland) Act 1919. The legislation has featured in contemporary commentary on land reform, with Scottish Green Party suggesting it should be revitalised.

${ }^{57}$ I. Scoones, 'Why Cecil the lion offers lessons for land reform and the role of elites' The Conversation 5 August 2015 at https://theconversation.com/why-cecil-the-lion-offers-lessons-for-land-reform-and-the-roleof-elites-45625. This article specifically considers the area where the lion was shot, which came into the ownership of an 'elite' of one of Zimbabwe's governing party. It is then noted that the 'new landowners' [including the owner of the land in question] 'hooked up with white safari operators' and in turn allowed a now infamous hunting trip to take place.

${ }^{58} \mathrm{Immediately}$ after airing the proposition that land reform 'enhances the protection of the environment and promotes sustainability...', Pienaar notes that 'promoting land reform and sustainability would depend on the size of the landholding, its location, the particular environmental surroundings and the needs of the community concerned, to name but a few.' Above n. 4 at 24 .
} 
right blend of land uses to best meeting policy objectives and societal demands'. ${ }^{59}$ Environmental concerns relating to owner choices might come to the fore in a more pronounced way in that squeezed middle.

\section{Redistributive Scottish Land Reforms}

If there was ever a time when the Scottish land question was not topical, now is not that time. ${ }^{60}$ The election of a Labour Government at the 1997 UK General Election brought the Scotland Act 1998, which in turn brought devolution to Scotland. The Scottish Parliament quickly embraced a land reform agenda, ${ }^{61}$ an agenda galvanized by the formation of the Land Reform Policy Group chaired by Lord Sewel. ${ }^{62}$ All of this paved the way for numerous legislative measures ${ }^{63}$ in the first term of the new devolved administration, including the Land Reform (Scotland) Act 2003, with brought two community rights of acquisition. The Scottish Parliament has also legislated on matters relating to the heavily regulated leases in the rural sector, namely agricultural holdings ${ }^{64}$ and crofts. ${ }^{65}$ These reforms were not generally about re-allocating property rights, but part of its agricultural holding reforms introduced a pre-emptive right of acquisition for agricultural tenants, who could register an interest in their holding in the hope of acquiring the land should the landowner ever choose to sell. ${ }^{66}$ That potential tenant right of acquisition can be contrasted with the much stronger right of acquisition that a crofter has in relation to his croft, which can be used to force a sale from a crofting landlord. ${ }^{67}$

59 This is discussed in the Final Report of the Land Reform Review Group, above n. 13 at Part 6 (Land Ownership and Use), Section 23 (Rural Land Use), paragraphs 21-23. It drew on the following extract from a paper by the James Hutton Institute: 'Those who own and manage [land in the squeezed middle] face multiple choices -it can support relatively intensive livestock farming and limited arable cropping: it often has high potential for tree growth, especially conifers; it contains some relatively intensively managed sport shooting land, especially grouse moors; and increasingly, some areas are managed for conservation or landscape protection. This area is also the living space for diverse rural communities.' B. Slee, I. Brown, D. Donnelly, I. J. Gordon, K. B. Matthews and W Towers, The squeezed middle: potential conflicts over Scotland's intermediate quality rural land (The James Hutton Institute, 2013), available at http://www.hutton.ac.uk/sites/default/files/files/events/Squeezed-Middle-discussion-paper.pdf.

${ }^{60}$ See Combe, above n. 7 at 196-200 for further background.

${ }^{61}$ Of course, land reform literature predates this era, including J. McEwen, Who Owns Scotland (EUSPB: Edinburgh, 1977) and J. Hunter, The Making of the Crofting Community (John Donald: Edinburgh,1976). It would also be simplistic to attribute all relatively modern reforms to the Labour victory in 1997, as it was a Conservative Government who implemented the Transfer of Crofting Estates (Scotland) Act 1997, a statute discussed further below.

${ }^{62}$ Three publications were produced by the Land Reform Policy Group and published by the Scottish Office: Identifying the Problems (1998); Identifying the Solutions (1998); and Recommendations for Action (1999).

${ }^{63}$ A number of other statutes relating were also passed, with a list detailed in Annex 4 of the Final Report of the Land Reform Review Group, above n. 13.

${ }^{64}$ As regulated by the Agricultural Holdings (Scotland) Act 1991 and the Agricultural Holdings (Scotland) Act 2003.

${ }^{65}$ Crofting is a form of landholding peculiar to certain parts of Scotland which gives the crofter (tenant) almost absolute security of tenure. Although the legal framework that established crofters as creatures of statute begins with the Crofters Holdings (Scotland) Act 1886 (now found in the Crofters (Scotland) Act 1993), crofting's story goes much further back. The starting point for any study is J Hunter's The Making of the Crofting Community (Birlinn: Edinburgh 2000) (first published 1976).

66 S. 25.

${ }^{67}$ Above n. 19. 
All of these measures have been innovative for Scotland in their own ways, but the desire for land reform never quite sated. Organisations and commentators continued to agitate for reform. The governing Scottish National Party appointed a group to look at land reform in 2012. This Land Reform Review Group produced its Final Report in 2014, containing 62 recommendations as to what the Scottish Government should do. ${ }^{68}$ Following this a further consultation on what the legislation should actually contain was undertaken, before a draft bill was published before the Scottish Parliament's 2015 summer recess, with a further Call for Evidence about the terms of that bill being made by the relevant scrutinising Scottish Parliament Committee. Running alongside this, the Scottish Affairs Committee got involved in the debate at a UK level. Although no Westminster legislation followed (or is likely to follow) from that intervention, the Committee gathered evidence and published two reports which add to the contemporary debate. ${ }^{69}$

Furthermore, much of this happened as a separate but related statute on community empowerment was working its way through Holyrood. The Community Empowerment (Scotland) Act 2015 makes a number of amendments to the $2003 \mathrm{Act}^{70}{ }^{70}$ widening the scope of its pre-emptive community right to buy to the whole of Scotland (rather than simply rural Scotland) ${ }^{71}$ and introducing a new right of community acquisition where land has been 'wholly or mainly abandoned or neglected' or somehow managed in a way that was detrimental to a community's 'environmental wellbeing'. ${ }^{72}$ The most recent legislative activity comes in the form of the Land Reform (Scotland) Act 2016, which (amongst other things) introduces another community right to buy land to further sustainable development and a stronger right to buy for some agricultural tenants, to allow tenants under the Agricultural Holdings (Scotland) Act 1991 to acquire a holding in certain circumstances, namely when a landlord is in material breach of an order of the Scottish Land Court or an arbitral award. ${ }^{73}$

The contents of the 2015 Act and the 2016 Act will be considered further below, but the scene is now set to consider how reallocation of property rights in Scotland has impacted, and might yet impact, on the environment.

\section{SCOTTISH REFORMS AND THE ENVIRONMENT}

It can be seen that redistributive land reforms in modern Scotland tend to be of two broad types: tenant rights of acquisition; and community rights of acquisition. Both of these can affect what happens on the ground.

\section{TENANT RIGHTS OF ACQUISITION}

\footnotetext{
${ }^{68}$ See Combe, above n. 13.

${ }^{69}$ Scottish Affairs Committee, Eighth Report - Land Reform in Scotland: Interim Report (2014), at http://www.publications.parliament.uk/pa/cm201314/cmselect/cmscotaf/877/87702.htm and Scottish Affairs Committee, Eighth Report - Land Reform in Scotland: Final Report (2015) at http://www.publications.parliament.uk/pa/cm201415/cmselect/cmscotaf/274/27402.htm

70 These reforms came into force on 15 April 2016, per The Community Empowerment (Scotland) Act 2015 (Commencement No. 3 and Savings) Order 2015 (SSI 2015/339).

${ }^{71}$ Community Empowerment (Scotland) Act 2015, s. 36, which amends the 2003 Act, s. 33.

72 S. 74, introducing a new Part 3A to the 2003 Act. [XXX Implementation date, Scottish Government consultation ends 20 June - https://consult.scotland.gov.uk/community-land-team/abandoned-land.]

${ }^{73}$ This change is made by the introduction of a new Part 2A to the Agricultural Holdings (Scotland) Act 2003.
} 
Simplistically, the environmental effect of a tenant acquiring land is inversely proportional to the rights that the former tenant enjoyed qua tenant. That is to say, a tenant with broad powers to make agricultural choices or perhaps even diversify from agricultural production ${ }^{74}$ will not actually gain many new powers as a result of upgrading (if that is the correct word) to ownership. The impact would be more pronounced where a tenant did not enjoy such rights. ${ }^{75}$ That said, in either situation the former tenant would have the more recognisable capital asset of ownership and the ability to manage the land on that basis. ${ }^{76}$

There is also an attraction to the idea that an owner of a small area - particularly when that is the owner's main asset - will take more pride and care in that asset than the manager of a large area would: consider some of the logic that surrounded the introduction of a right to buy in social housing. Whether that pride and connection might lead to more productive land use is a difficult issue to contend with and it will not be analysed here. ${ }^{77}$

The key environmental considerations therefore are: whether the use of land in a landlord and tenant situation is environmentally sound; and whether the exercise of a right to buy could change that.

If the answer to the first question is 'yes', there would be a weak environmental argument for reallotment. Instead, security of tenure for a tenant - which many rural tenants in Scotland already enjoy - together with a fair system of rent review to keep the system viable and assignation ${ }^{78}$ and succession rules to allow the system to continue could be seen as adequate protection for the environment ${ }^{79}$ and (assuming the system worked fairly and food productivity was not threatened)

\footnotetext{
${ }^{74}$ Such as those introduced by the Agricultural Holdings (Scotland) Act 2003, s.40.

75 T. Hanstad, R. L. Prosterman and R. Mitchell, 'Poverty, law and land tenure reform' in Prosterman, Mitchell and Hanstad, above n. 39, 17 at 36 list ten ways secure land rights can facilitate economic development as compared to weak or insecure rights. For present purposes, it can be noted that one of the ways they list is 'reducing soil erosion and other environmental degradation to land as the result of incentives to improve stewardship of land.'

${ }^{76}$ Owning the land can be useful when it comes to accessing credit markets, as lenders are traditionally sceptical when it comes to advancing money secured on anything other than ownership.

${ }^{77}$ A diverse range of literature is available on this point. See K. Deininger and H. Binswanger, 'The Evolution of the World Bank's Land Policy: Principles, Experience, and Future Challenges' The World Bank Research Observer,(1999) 14 (2) 247 at 251, who highlight that there is 'evidence that hired labor is less productive than family labor'. See also G. Feder, 'The Relation Between Farm Size and Farm Productivity: The Role of Family Labor, Supervision and Credit Constraints' (1985) 18 Journal of Development Economics 297 (which also considers the impact of imperfect credit markets), G. A. Cornia, 'Farm Size, Land Yields and the Agricultural Production Function: An Analysis for Fifteen Developing Countries' (1985) 13(4) World Development 513, D. Benjamin, 'Can unobserved land quality explain the inverse productivity relationship?' (1995) 46 Journal of Development Economics 51, and Pienaar, above $\mathrm{n} 4$ at 35 . Further research on the relationship of different patterns of landholding size to social, economic and environmental outcomes was commissioned by the Scottish Government's Rural and Environment Science and Analytical Services and is keenly awaited: see http://www.gov.scot/Topics/Environment/land-reform/Development.

78 'Assignation' is the Scots term for the English equivalent of 'assignment'.

${ }^{79}$ Whilst not relevant to this discussion about reallocation of ownership, the environment did feature at Stage 3 of the Scottish Parliamentary process in a discussion about the let sector, where Richard Lochhead (the Cabinet Secretary for Rural Affairs, Food and Environment) said 'supporting our tenant farming sector is crucial and a major feature of the bill has been how we open up opportunities for new entrants, how we give those who want to retire dignified routes of exit and how we ensure that more land is available to let in Scotland so
} 
society as a whole. ${ }^{80}$ There may be separate non-environmental arguments for land reform, and if there are the second question comes to the fore: how do you prevent a new owner from causing harm? A mixed answer involving clawback rules, ${ }^{81}$ education programmes and indeed the prevailing regulation of the environmental obligations of all landowners would form part of the answer to that.

If the answer to the first question is 'no', the question turns to whether an incoming owner could do things that will improve the environment. As noted, a small landholder might be expected to take more care of an asset, but that would need to be traded off against the upheaval and education implications land reform can involve. Then again, upheaval should be minimal where a tenant is already on the ground. Where a landlord owns a much larger area than the subjects of the lease, a tenant acquisition might be a potential loss from the economy of scale such a large landowner would enjoy, or there may be situations where losing (the income from) the best arable land in an area might make management of the rest of the estate unviable. ${ }^{82}$ Another natural consequence of smaller units is that any set-aside of land (for regeneration or to help birdlife in the area) would immediately affect a greater proportion of the unit, which would make such a step far less attractive for those seeking maximum productivity.

A tenant right of acquisition does, therefore, have implications for the environment, but those are difficult to separate from questions about security of tenure and the implications may not be as profound as other situations where there are not simply plans for a new owner to carry on with more of the same. That brings us to the second model of re-allocation that has prevailed in Scotland, namely community rights of acquisition.

\section{COMMUNITY RIGHTS OF ACQUISITION}

As already highlighted, the community ownership story in Scotland has many strands to it. The first real statutory intervention came in the form of the Transfer of Crofting Estates (Scotland) Act 1997. This legislation provides for community acquisition of crofting lands owned by the state. The incoming crofting landlord would be a community body. No particular change of land use was

that we have people putting food on our tables and caring for our environment.' (Emphasis added.) Official Report 16 March 2016 Col 217. Reforms to agricultural holdings can be found in Part 10 of the 2016 Act. 80 Such an approach very much ties in with the traditional justification for agricultural holdings legislation in general, illustrated by Lord Salvesen in one notable judgment concerning the Agricultural Holdings (Scotland) 1883. That legislation provided for compensation for tenants' improvements and encouraged maintenance of soil fertility in the latter years of a lease, and Lord Salvesen postulated that the main object of the 1883 Act was to encourage the best methods of cultivation so that the land might be made most productive to the tenant in his interest and the interest of the community at large.' Earl of Galloway v M'Clelland, 1915 SC 1062 at 1099.

81 If the existing land use was environmentally sound, any system that allows a former tenant alter the use of the land in question after acquisition, without fear of some kind of clawback mechanism, would need to be considered very carefully.

${ }^{82}$ An analogy with crofting law might be apposite here. In terms of the Crofters (Scotland) Act 1993, s. 13, the Scottish Land Court shall not make an order compelling transfer where 'in all the circumstances pertaining to the landlord and having regard to the extent of land owned by him to which this Act applies, the making of such an order would cause a substantial degree of hardship to the landlord' and/or 'that the making of such an order would be substantially detrimental to the interests of sound management of the estate of the landlord of which the croft land to which the application relates forms part.' 
envisaged, as the land would remain under the highly regulated regime of crofting tenure. ${ }^{83}$ Any resulting environmental impact of a transfer would therefore be low. As it happens, the actual impact of that statute has been low in any event: only one community, West Harris, availed itself of the legislative scheme.

Perhaps the real impact of the 1997 Act was to place community at the fore of any future legislative intervention. The Land Reform Policy Group embraced community acquisition in its work, and in so doing acknowledged - at least tangentially - the positive effect a community might have on its environment. One LRPG document drew on consultation responses to highlight two key themes, one of which was the following:

'increased diversity in the way land is owned and used, as the best way of dealing with damage to the local community or environment which can result from monopoly ownership, and of encouraging the fullest possible exploitation of rural development opportunities. ${ }^{84}$

The opening clause of that extract makes clear that shaking the existing ownership pattern as a way of dealing with damage to the environment was part of the thinking of the LRPG. This theme was not specifically about community acquisition, but other extra-statutory developments in Scotland perhaps channelled the LRPG into thinking more about community models. High profile buyouts occurred in places like Gigha, Assynt and Eigg. The environment also played a role in the story of the latter, but it in a somewhat curious way. The body representing the community sought assistance from all sorts of sources to finance the acquisition of land, including The Heritage Memorial Fund. That was one of the grant-giving bodies established by the relatively young National Lottery, who 'turned down a request for assistance on the bizarre basis - as it appears in retrospect - that, if the Isle of Eigg Heritage Trust was successful, islanders would thereby be given too large a say in what was to happen on an island which, the Memorial Fund agreed, was of national significance environmentally. ${ }^{85}$ The residents of Eigg managed to find alternative finance (including via anonymous philanthropy), which empowered them to such a degree that they recently won the Ashden ${ }^{86}$ award for an innovative renewable energy scheme. This mixture of hydro, wind and solar (supported by a bank of batteries and, if necessary, a back-up diesel generator) goes some way to making the island self-sufficient for energy, all the while making the Memorial Fund's refusal grounds more questionable with hindsight. It also gives a prime example of a community making environmentally sound decisions, ${ }^{87}$ and as we have seen the community model was something that the Land Reform Policy Group advocated in its output. ${ }^{88}$

\footnotetext{
${ }^{83}$ There are processes to remove land from the control of crofting law, known as resumption and decrofting, but both are somewhat convoluted and no analysis will be made of them here.

${ }^{84}$ Emphasis added. See Land Reform Policy Group, Identifying the Solutions (The Scottish Office, 1998) at para 3.2 .

${ }^{85}$ Hunter, above n. 41 at 92.

${ }^{86}$ See http://www.ashden.org/winners/Eigg10. The Ashden homepage explains the award thus: 'Established in 2001, the Ashden Awards are a globally recognised measure for excellence in the field of green energy.'

${ }^{87}$ Notably, the Scottish Environment Protection Agency, in its response to the most recent Scottish consultation on land reform which included consideration of community ownership of land, SEPA noted that 'we support the principle of community ownership and note that the consultation proposals will be a major step in achieving this,' although that was caveated by the need for a 'robust sustainable development test' https://consult.scotland.gov.uk/land-reform-and-tenancy-unit/land-reform-
} 


\section{First wave community rights of acquisition}

The 2003 Act followed on from the preparatory work of the LRPG. It works by allowing a community body (i.e. members of a locality associated together in a suitable juristic persona) to acquire land in certain circumstances. Those circumstances involve a number of preparatory steps, including a ballot to ensure there is local interest, and even then acquisition will only be possible with the approval of the Scottish Ministers. That approval will only be forthcoming if the acquisition is in the public interest and compatible with furthering the achievement of sustainable development. ${ }^{89}$

Whilst the environment might not appear prominently in the words of the statute, it undoubtedly features as a subset of sustainable development, and perhaps within the wider notion of public interest. Both of these factors are at play when the exercise of a pre-emptive right to buy under Part 2 or a forced sale under Part 3 of the 2003 Act is sought, whilst a commitment to sustainable development is also a condition precedent before recognition as a qualifying community body can be granted. ${ }^{90}$ There is also an extra requirement for sustainable development in Part 2 where a community seeks to register an interest to acquire land that is near (rather than within) that community. ${ }^{91}$ The role of sustainable development in this statute has been described as a 'primary duty' on the decision-makers which 'has priority over any other duties or objectives', ${ }^{92}$ so its application and interpretation is of crucial importance. A conscious decision was taken by the legislature not to define the term 'sustainable development' in that statute: in fact, Holyrood dropped a definition as the bill passed through Parliament, to leave the term untrammelled by statutory language. ${ }^{93}$ This approach was vindicated in court when an attack on the vagueness of the term was given short shrift. ${ }^{94}$ (The term remains undefined in later land reform legislation.)

scotland/consultation/download public attachment?sqld=question.2013-10-30.9602267046publishablefilesubquestion \&uuld $=12900850$

${ }^{88}$ There is not much in the way of international analysis in the work of the Land Reform Policy Group, but it can be noted that precedents for community-centric land reforms can be found in other jurisdictions, such as South Africa (see the Communal Property Associations Act, 1996 [No. 28 of 1996]) and Peru (for example, the Land Reform Act of 1969 largely resulted in the transfer of land co-operatives or communities, rather than individuals). More recently, Scottish civil servants have engaged in some welcome comparative work: see the Scottish Parliament Information Centre Briefing 15/38, International Perspectives on Land Reform (SPICe: Edinburgh, 2015), at http://www.scottish.parliament.uk/parliamentarybusiness/91179.aspx. Interestingly, the Executive Summary of that Briefing indicates that Scotland may be swimming against the tide in its fondness for community ownership, which is is in contrast to the apparent European trend towards increasing land consolidation. The Community Right to Buy and Crofting Community Right to Buy...are correspondingly unique pieces of existing legislation, despite the growing Community Land Trust movement in North America and Europe, and draft legislation in Kenya that seeks to restore and register community land rights.'

${ }^{89}$ S. 51(3)(c) and (d) (for the Part 2 community right to buy) and s. 74(1)(j) and (n) (for the Part 3 crofting community right to buy).

${ }^{90}$ Ss. 34(4) and 71(4).

${ }^{91}$ S. 38(1)(b)(ii).

${ }^{92}$ A. Ross, Sustainable Development in the UK: From Rhetoric to Reality? (Earthscan: Abingdon, 2012) 191.

${ }^{93}$ Combe, above $\mathrm{n} 7$ at 219-222.

${ }^{94}$ Pairc Crofters Limited, above n. 31. That is not to say interpretive issues do not remain: see Ross, above $\mathrm{n}$. 91 , chapter 8 and particularly at 193, where she analyses situations where economic, social and environmental considerations have all been given different weightings in decisions relating to sustainable development. 
The key litigation on the terms of Part 2 makes clear that a community should tread carefully if a main driver for the attempt to acquire land is meant to thwart development. ${ }^{95} \mathrm{Holmehill}$ Limited $v$ The Scottish Ministers ${ }^{96}$ involved a community trying to exercise a pre-emption right before a transfer to an incoming owner with specific plans for the site - which had obtained planning permission. For a number of reasons, the community was unsuccessful, but one point that can be teased from this and other litigation to date is that the environmental element is not a trump card in amongst the three interrelated elements of economic, social and environmental goals that are generally accepted within the definition of sustainable development. ${ }^{97}$ This seems to be a salutary warning that buyouts for purely conservation purposes will not be looked on favourably.

There have also been occasions where a community had plans which would have, on most analyses, improved the local environment. One example comes from the Renfrewshire village of Lochwinnoch, where a community took a number of steps to acquire an old bottling plant. As a result of the scheme of Part 2 of the 2003 Act, which can only apply when the owners wish to sell, the owners of the derelict building were able to pull out of the transaction notwithstanding all the energy the community had put into it. For present purposes, it can be noted that the environment remained as it was, and no ready case-study has been provided about the impact of a reallocation of ownership. ${ }^{98}$ As for the impact of the Part 2 scheme as whole, some analysis is available from a 2008 study, albeit this states 'relatively few environmental impacts were noted.' ${ }^{99} \mathrm{~A}$ more recent study shows some indication of 'environmentally sustainable use of land and land assets', but caveats this by noting there was only 'limited evidence' for this. ${ }^{100}$

The impact of the Part 3 scheme on the environment is also difficult to quantify. ${ }^{101}$ As with the 1997 Act already mentioned, the crofting community right to buy was not designed to steer any community that acquired land away from traditional crofting usage. That being the case, the right to acquire croft holdings, common grazings in crofting townships and certain 'eligible additional land' around such crofts and grazings has certainly influenced landowner behaviour, and indeed much of the Western Isles, a key crofting area, is now owned by a variety of community bodies who could approach land use decisions in a different way to the immediately preceding owner. Although this is speculation, the Part 3 powers might have mitigated on-shore wind farm plans, particularly on the

\footnotetext{
95 M. M. Combe, 'No Place like Holme: Community expectations and the right to buy' (2007) 12 Edinburgh Law Review 109.

962006 S.L.T. (Sh Ct) 79.

97 See also M. M. Combe, 'Access to Land and to Landownership' (2010) 14 Edinburgh Law Review 106, which discusses the case of Hazle $v$ Lord Advocate (Kirkcaldy Sheriff Court (ref B270/07), 16 March 2009).

98 One contrast might be noted with the Localism Act 2011 here: whilst the Scottish regime in force at the time was unable to force a sale to a community, in that the landowner could choose to no longer sell, it did mean the community would not be forced to contend with a new landowner, as any transfer that did not first consider the community could have been open to challenge. The new Part 3A of the 2003 Act will provide a power of compulsion in certain circumstances, so a different result may be reached in future.

${ }^{99}$ B. Slee, K. Brown, K. Blackstock, P. Cook, J. Grieve and A. Moxey, Monitoring and Evaluating the Effects of Land Reform on Rural Scotland: a Scoping Study and Impact Assessment (Scottish Government Social Research, 2008) at paragraph 7.30, available at http://www.gov.scot/Publications/2008/06/12121207/0.

100 See also Mulholland et al, above n. 41 at paragraph 5.98, where it is noted: 'There was limited evidence of land or assets being used in a more environmentally sustainable way. Case studies did give examples, however, of improvements to land to make them more energy efficient and reduce fuel consumption.'

${ }^{101}$ In relation to the crofting community right to buy the 2008 study noted that 'built and environmental effects are unlikely to have developed at this point.' Slee et al, above n. 100 at paragraph 8.30.
} 
Isle of Lewis. ${ }^{102}$ Any new energy schemes in crofting areas that are community owned will likely be designed in the locality itself, or at least with community involvement, which will arguably allow more appropriate schemes to be developed than might have been the case otherwise. Again, it is difficult to comment on what might have been without venturing into the realms of the counterfactual, but (non-statutory) community projects, like Gigha's three wind turbines or Eigg's energy scheme, provide anecdotes from other communities. ${ }^{103}$

In terms of community acquisition more generally, the points made about tenants can apply for communities mutatis mutandis. That is to say, a community might be expected to take more care of an asset when that is all it has and perhaps benefit from local knowledge as compared to that unit being part of a much larger estate, but that needs to be measured against potential loss of the economy of scale, making an existing estate unviable by a community cherry-picking the best land, reducing opportunities to set-aside land, and any upheaval and education implications land reform can involve.

\section{Second wave community rights of acquisition}

The 2003 Act will soon have a new Part 3A, introduced by the Community Empowerment (Scotland) Act 2015. ${ }^{104}$ Section 74 of the 2015 Act enshrines a right which goes beyond pre-emption, meaning this new entitlement has something in common with the crofting community right to buy, found in part 3 of the 2003 Act, which does not require a willing seller. Properly constituted community bodies are to be given the right to acquire 'eligible land' if (in the opinion of Scottish ministers): '(a) it is wholly or mainly abandoned or neglected, or (b) the use or management of the land is such that it results in or causes harm, directly or indirectly, to the environmental wellbeing (emphasis added) of a relevant community'. Quite rightly, such profound effects will not be unlocked automatically: consent for community acquisition will only be given where ministers are satisfied that the land is in fact eligible (i.e. abandoned, neglected or environmentally detrimental) and that the exercise of the right is both in the public interest and 'compatible with furthering the achievement of sustainable development'. ${ }^{105}$

The first limb of this new right of acquisition was expected and consulted on widely. Limb (b) was a Stage 3 amendment at Holyrood, meaning it came at the last moment of the legislative process and was not considered in detail by a committee of the Scottish Parliament. It was introduced by a Scottish Government amendment in the name of Aileen McLeod, the Minister for the Environment, Climate Change and Land Reform. For present purposes, its explicit provision for 'environmental wellbeing' is tantalising: here is a land reform power that specifically grants a power to a community, implicitly because it will do better for the environment (or at least environmental wellbeing) than the present owner.

\footnotetext{
102 If, and it is a big if, the renewable schemes did not happen because of the engagement of various communities, it should be noted that this community feeling was embodied in a number of ways that were not necessarily about taking ownership, including pressure groups like Mòinteach gun Mhuileann/Moorland without Turbines (see http://www.mwtlewis.org.uk/).

103 See generally Hunter, above n. 41.

104 See further M. M. Combe, 'Digesting the Community Empowerment Act' (2015) 60(8) Journal of the Law Society of Scotland 40.

${ }^{105} \mathrm{~S}$. $97 \mathrm{H}$ of the 2003 Act.
} 
How this will be applied in practice is not immediately clear. The language leaves a lot to interpretation. The legislation does clarify that 'harm' includes environmental effects which 'have an adverse effect on the lives of persons comprising the relevant community', but 'does not include harm which, in the opinion of Ministers, is negligible'. One aid to interpretation might be found in local government law and its treatment of the term 'environmental well-being' as it appears there, ${ }^{106}$ but the clearest guidance comes from the Official Report of the Scottish Parliament.

Proceedings at Stage 3 of the bill give some insight as to what the term means, and what it does not mean. The first step in unlocking this new power is not tied to sustainable development: in fact, at Stage 2 a right of acquisition for when land was 'in substantial need of sustainable development' was proposed, but that did not make the final cut. What did happen at Stage 3 was a number of amendments to widen the definition of 'eligible land' via the new harm to 'environmental wellbeing' test, with the relevant Scottish Minister noting:

Environmental wellbeing is not being defined in the bill as I want it to have a broad meaning for the purposes of part 3A of the 2003 act and not to be restricted to harm that is caused to just the physical condition of the community. Harm to the community's environmental wellbeing, for example, may affect the amenity of the community. That may include cases where the use or management of the land causes or results in harm to the community such as the detrimental impact that a group of boarded-up shops, unoccupied housing or algaefilled ponds that are becoming health hazards might have on the community's environmental wellbeing. ${ }^{107}$

Three examples are given. At first glance, these examples may also have fallen within the 'wholly or mainly abandoned or neglected' route to acquisition, but there are some important differences in the wording of the 'harm to...environmental wellbeing' route, not least of which is the emancipation from the words 'wholly or mainly'.

Beyond those examples, all that is definitely clear is that it is not just the physical condition of the community. Relatedly, an opposition MSP (Sarah Boyack) sought to insert 'and social' into the drafting. That was resisted, and the clarification is instructive. McLeod stated, 'I reassure members

\footnotetext{
${ }^{106}$ Regulation 4 of the Disposal of Land by Local Authorities (Scotland) Regulations 2010 (SSI 2010/160) provides a 'local authority may dispose of land for a consideration less than the best that can be obtained' where one of four purposes are promoted, namely: economic development or regeneration; health; social well-being; or environmental well-being. (For reasons that are not immediately clear, 'wellbeing' is a compound word in the 2015 Act, but hyphenated as 'well-being' in the local authority legislation.) Regulation 4 directs that 'well-being' is to be construed in line with the Local Government in Scotland Act 2003, s.20, which in turn gives a wide-ranging remit to do anything "in relation to, or for the benefit of, any persons or place outwith the area of the local authority; or (b) in any such place, if the authority considers that doing so is likely to achieve the purpose set out in [s. 20(1)]." There is not much case law on this section, and the only case that was called upon to judge how far the well-being power could be stretched found that it could not be used to displace rules to relating to inalienable common good land: see Portobello Park Action Group Association v City of Edinburgh Council [2012] CSIH 69, which was about the attempted appropriation of parkland for use as a school, analysed in M. M. Combe, Lessons in Scots law: the common good school (2013) 17 Edinburgh Law Review 63. Incidentally, the rules about common good land that were at issue in the Portobello case have been reformed by Part 7 of the 2016 Act.

107 The Scottish Parliament Official Report, Meeting of the Parliament Wednesday 17 June 2015, at 116, available at http://www.scottish.parliament.uk/parliamentarybusiness/report.aspx?r=10020\&mode=pdf.
} 
that the definition of environmental wellbeing has a wide meaning and encompasses some social considerations.' 108

This could be a very important power. What is the policy justification for this right? Can we be confident the community will look after the environmental wellbeing of a newly acquired asset? Another question to consider is whether this is a test that might properly be levelled at large land areas. The examples seem to illustrate that this is actually aimed at smaller, more strategic acquisitions, so is this just paying lip-service to the environment? And perhaps most crucially of all, notwithstanding that analysis which sets up environmental wellbeing as a standalone term independent of sustainable development, ${ }_{-}^{109}$ there is still a sustainable development requirement that Scottish Ministers need to be satisfied on before consent for community acquisition will be granted. As noted above, that test can have a profound impact and some environmental buyouts (that is to say, buyouts that are not predicated on development) could be very firmly nipped in the bud.

\section{Third wave community rights of acquisition}

On 16 May 2016, the Scottish Parliament approved a new land reform statute. It contains a number of important measures, with much of it being dedicated to the matter of agricultural holdings reform and other provisions for diverse issues like community engagement, deer management, and a new body called the Scottish Land Commission to monitor matters relating to land. In terms of redistributive land reform, Part 5 of the Act is of most interest. It provides for a community right to acquire land to further sustainable development, adopting a community-centric model not unlike Parts 2, 3 and 3A of the 2003 Act. As per the 2003 Act, sustainable development is not defined, but again it can be taken as a given that the environment is a factor in the sustainable development mix. The environment does feature within one of the considerations for Scottish Ministers when deciding to grant (or not grant) consent to a transfer, in terms of the 'environmental wellbeing' of the community that seeks a transfer, ${ }^{110}$ but it is not of central importance: in fact, it only features at the end of a very onerous process that communities might find it difficult to get through. That being said, the process is onerous because this right of acquisition does not require a willing seller: when those tests are met, and subject to payment of an agreed or independently valued price, transfer is compelled.

\footnotetext{
${ }^{108} \mathrm{lbid}$. at 118. In response to McLeod, Boyack (at 119) noted her motivation for lodging her amendment was to probe what was meant, and welcomed the 'wider definition that she has put on the record this afternoon is helpful in making it clear that the term includes social wellbeing.' She then continued: 'It is important to have it on record that environmental wellbeing is seen in a broader context, that it is not just about physical conditions, that it is important to urban and rural communities and that it is all about the use and management of the land. Crucially, the minister referred to boarded-up shops-which could, of course, mean other boarded-up buildings that have been left vacant for some time-or ponds that are causing harm... The fact that the term "environmental wellbeing" is seen as covering impacts on human health and social wellbeing is helpful to us in moving forward.' It can be noted that this seems to contrast with the Disposal of Land by Local Authorities (Scotland) Regulations 2010, where social and environmental well-being are separate considerations.

${ }^{109}$ S. $97 \mathrm{H}$ of the 2003 Act.

${ }^{110}$ Section 47 of the 2016 Act. XXX CHECK NUMBERING ONCE ROYAL ASSENT APPLIED
} 
The power in Part 5 is innovative in a Scots law context, and it may well have the impact of opening up dialogues between owners and communities that are not open at present. From a redistributive land reform point of view, the number of times the scheme is actually called upon may be limited by the hurdles involved in the scheme. From a specifically environmental point of view, it is notable that sustainable development remains the currency, of which the environment is but a part. Whilst there were moves to bring environmental matters to the fore in the $2015 \mathrm{Act}$, these have perhaps slipped to the background. The only other occasions the environment features in the text of the 2016 Act are in relation to deer management (in terms of the potential for imposition of a deer management plan when deer have caused or are likely to cause environmental damage) and also in terms of the qualifications the new Scottish Land Commissioners should hold.

One final thought springs to mind: what of the environment when there is no human community? If the environment really is a driver for land reform, should reform be predicated on an existing community at all? None of the powers listed above, existing or proposed, come into play where there is no resident or existing population. Are there environmental arguments for human resettlement, as provided for by the Congested Districts (Scotland) Act 1897 and the Land Settlement (Scotland) Act 1919? Or are advocates of environmental protection in Scotland in fact best served by acquiring land on the open market and then using that land for conservation purposes? That practice is not free from criticism, but it is still evident in Scotland. ${ }^{111}$ In fact, that practice was highlighted in the book review that provided the introduction to this essay, ${ }^{112}$ which full circle now provides an opportunity to draw this article to a close.

\section{CONCLUSION}

Scotland is a fascinating land reform case study at the moment. Its mixed legal system makes it a prime candidate for comparative legal research anyway, ${ }^{113}$ while recent devolution and the even more recent independence referendum means long established notions of how its society should be structured and governed are being challenged.

Whether or not landowners are a legitimate target for such a challenge is itself a challenging question. To its credit the representative group for landowners, Scottish Land and Estates, is engaging with the process in full and has provided responses to the various Government consultation exercises. Its response to the Land Reform Review Group was lengthy. ${ }^{114}$ Within that

\footnotetext{
111 In 2014, it was noted that eight of these environmental organisations own a combined total of 202,391 hectares, which is equivalent to $2.6 \%$ of Scotland's land area: Final Report of the Land Reform Review Group, above n. 13, Part 6 (Land Ownership and Use), Section 24 (Pattern of Rural Land Ownership), paragraph 9. 112 Combe, above n. 1 at 243.

${ }^{113}$ For example, see R. Zimmermann, K. Reid and D. Visser, Mixed Legal Systems in Comparative Perspective: Property and Obligations in Scotland (Oxford University Press: Oxford, 2005).

114 The 140 page document is available on the Scottish Land and Estates Website at http://scottishlandandestates.co.uk/index.php?option=com content\&view=article\&id=2254:land-reformresponse\&catid=142:land-reform-data\&ltemid=232
} 
response, there were times when the existing landowners positioned themselves as custodians of land. ${ }^{115}$ Representations to this effect were also made to the Scottish Affairs Committee. ${ }^{116}$

The idea of people in Scotland looking to stewards to care for them and the land is not in any way new. A verse of the Gaelic song Gaoir nam Ban Muileach (which translates as 'The Cry of the Mull Women') is dedicated to a lost Isle of Mull landowner, with the mournful singer challenging anyone with eyes not to perceive 'the change which has come on our land since the day we lost the one man who protected us, under God's hand', before noting (no doubt with poetic licence), that 'Our apple trees and apples have been stripped by the wind, every flower and fresh rose has gone, and our forest has been stripped of its beauty'. ${ }^{117}$ Whilst circumstances have moved on since the Jacobite uprisings that moved the Mull women to song, ${ }^{118}$ Scottish landowners continue to have a profound, agenda-setting part to play in the environment. If those landowners really are proper custodians of land, then the environmental arguments for land reform will not be strong. If they are not, and absent any emergence of a general duty of environmental stewardship, ${ }_{-}^{119}$ redistributive land reform can have a part in addressing that, but it should explicitly consider how and when environmental considerations feature in any equation, and provide for proper environmental management by any transferee.

Scotland has taken some small steps towards doing that, including a recent statute that explicitly refers to environmental wellbeing and a Ministerial role that combines the titular roles of environment and land reform, but should it lengthen its stride? Although this article uses the legal framework for Scottish land reform as its main reference point, it is hoped that it can provide a platform from which further work can consider what the environmental effects of legislative action can be both in Scotland and further afield. The environment should feature in the modern land reform debate and inform any future statutory changes. If a land reform framework that puts existing and prospective owners on notice about environmental concerns can be created, the benefits to nature should flow naturally.

115 Including in the foreword and in Appendix 7. That appendix was a pro forma response sent to members for Scottish Land \& Estates to gather information prior to its response to the Call for Evidence issued by the Land Reform Review Group, which stated, "Our members are responsible custodians of rural land...".

${ }^{116}$ The language used there was of 'stewardship'. See Scottish Affairs Committee, Eighth Report - Land Reform in Scotland: Interim Report (2014) at paragraph 10, at http://www.publications.parliament.uk/pa/cm201314/cmselect/cmscotaf/877/87706.htm\#a1.

${ }_{117}$ Margaret MacLean, with versions found in W J Watson, Bàrdachd Ghàidhlig (An Comunn Gàidhealach, Glasgow 1918) and John MacKenzie's Sàr-Obair nam Bàrd Gaelach (McGregor, Polson \& Co, Glasgow 1841/Keltia Publications 2001), with a performance available at www.tobarandualchais.co.uk/en/play/75908;jsessionid=610506C83C5404EB17D4FC291F80DE6F. This was the prescribed piece at the Gaelic music festival the Mòd Naiseanta Rioghaill in 2015, as arranged by Mary Ann Kennedy. In the original Gaelic, the verse is as follows: 'Cò am fear dha bheil sùilean dha nach soilleair a mhùthadh, A th' air teachd air ar dùthaich on là chaill sinn an t-aon fhear fo laimh Dhè ghabh dhinn cùram? Fhrois ar $n$-abhal 's ar $n$-ùbhlan, $d h$ ' fhalbh gach blàth agus ùr ròs, 's tha ar coill' air a rùsgadh dha h-ailleachd.' ${ }^{118}$ Much has been, and much more could be, written about how this era shaped the distribution of land across Scotland. For present purposes, it can be simplistically explained that the traditional stewardship role of the clan chiefs was essentially rendered into proprietorship, and that (coupled with a Hanoverian victory at Culloden more) afforded a degree of autonomy to clan chiefs or their successors that, sooner or later, resulted in profound changes to much of the Highlands, including the Isle of Mull.

${ }^{119}$ C. Rodgers, 'Property rights, land use and the rural environment: A case for reform' (2009) 26S Land Use Policy S134. 